\title{
「折」を生かした日本独自の描画法「扇」の数理的解明の試み
}

\author{
山崎 桂子*1，阿部 富士子*2，萩原 一郎 ${ }^{* 3}$
}

\section{Mathematical elucidation of the traditional Japanese fan focusing on its structure}

\author{
Keiko YAMAZAKI ${ }^{* 1}$, Fujiko ABE $^{* 2}$ and Ichiro HAGIWARA ${ }^{* 3}$

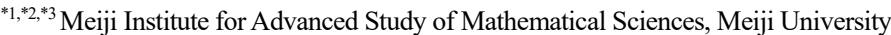 \\ 4-21-1 Nakano, Nakano-ku, Tokyo 164-8525, Japan
}

Received: 25 January 2021; Revised: 16 March 2021; Accepted: 27 April 2021

\begin{abstract}
Japanese traditional fan has the variety of three-dimensional expression that differs from two-dimensional expression. The image painted on the fan deforms, when it is folded into convex-concave configuration and fixed to the bamboo bones, due to the difference between the shrinking percentage of the outer arc and the inner arc. Many of the fans made until the Edo era are thought to be painted in consideration of the deformation, but this idea is not recognized in the field of traditional Japanese art. Therefore, many culturally valuable fans, which are more or less damaged due to aging, have lost their bones and damaged edges, and stretched flat like paintings. The fan surface is preserved but the original value of the fan is lost. In this study, we create a digital fan model by proposing approximate formulas for clarifying the deformation on the fan face according to parameters such as length of the bamboo bones, to support the opinion that three-dimensional configuration is essential for folding fans. We then validate the digital model with an actual fan. Regarding shape and area, there was good results, although further study is necessary to improve it. Furthermore, we obtain the original plan view from images of the folded fan as a reverse problem, which is useful for product development that makes use of the characteristics of folding fans.In future study, we would like to upgrade this model to the tool that assists the difficult task of reproducing folding fan without its original configuration. Also we would like to capture precious folding fans in three-dimensional space applying this model and to exhibit those fans in a digital museum, to give opportunities not only to enjoy the value of them but also to encourage the research of the Japanese traditional culture.
\end{abstract}

Keywords: Origami engineering, Image processing, Folding fan, Digital fan model, Deformation of fan drawing, Difference of fan image before and after folding, 3D paintings, Reverse problem, Design philosophy

\section{1. 緒言}

和紙と竹骨を使って折り畳み仕立てられた扇は，1000 年以上の歴史があり，日本で独自の発展を遂げた（李， 2007，朱，2020)。中でも，俵屋宗達，葛飾北斎，歌川国貞ら江戸時代に華々しく活躍した絵師の手がけた扇が 世界に数多く遺されている。このような絵師らによって手がけられた扇は，保存のために骨を外され表装されて いるものも多い，扇から骨を外し表装する際には扇絵の傷んでいる部分が切り落とされることが多く，また，場 合によっては折り目の位置や数及び扇骨の数や長さ等の情報も失われる. 扇絵の構図は「扇」の凹凸を読み取り， 骨と一体化した立体造形として扇に仕立てられたときに効果を発揮する構図で描画されたという捉え方が示され ている（阿部，2021）。従って，表装された扇は再現扇を作成することで初めて本来絵師の意図した構図で鑑賞 することが可能となるのであるが，現在残された情報から再現扇を実際に復元するには多くの手作業での試作が

No.21-00042 [DOI:10.1299/transjsme.21-00042], J-STAGE Advance Publication date : 13 May, 2021

*1 正員, 明治大学先端数理科学インスティテュート（テ164-8525 東京都中野区中野 4-21-1）

*2 明治大学先端数理科学インスティテュート

*3 正員, 名誉員, フェロー, 明治大学先端数理科学インスティテュート

E-mail of corresponding author: keyyamazaki@meiji.ac.jp 
必要となり限界がある．例えば，既に再現扇として世に認められているものについて，阿部らが欠損部分や折目 の見直しを綿密に行うことで再現が誤っていたことを指摘しているが，一本の扇について再現扇を何本も作成し ては比較し, 扇の作者の意匠に最も沿うであろう作品に近づけてゆくという膨大な作業の結果である(阿部, 2020). これをデジタル上で行うことが可能になれば，より多くの検討をより容易にかつ幅広く行うことが可能となる. 本研究では, 再現扇の復元検討を支援することと, ゆがみと折りを生かした表示ツールとしての扇の商品開発を 行うことを目的として, 絵師が検討に次ぐ検討の歴史の中で築き上げていたと思われる画像変換の仕組みを変換 式で表すことでデジタル上での扇の再現を試み，基本的な図形の画像で変換式を検証する.

既存の扇研究については阿部の文献に詳しいが, 扇は手に持ち開閉して鑑賞するという特徵のために他の文化 財に比べて劣化から保護するという観点で扱いが難しく, かつ世界に広く収蔵されていているためアクセスが困 難であることから，実物を対象にする研究には限界がある，従って，扇のデジタル解析を可能にする仕組みが扇 の研究に大きな貢献となると考える，既に，阿部らは扇をデジタルで表現することを試みているが，現時点では 扇の折の凹凸を考慮せず平面に投影した二次元の表面画像が得られたにとどまっている．扇を幾何学的に扱った ものとして他に面出らの論文がある（面出, 2007），扇絵は扇に仕立てられるとゆがみが生じるため, 扇で意図 した図が得られるよう平面画である扇絵には最初からゆがみが与えられる.このゆがみを持つ扇絵を同じ 2 次元 の矩形面上に変換してゆがみの特徵を掴むことを目的としている.これに対し, 本研究では扇の凹凸を考慮した 上で，扇骨のサイズに従う扇面のゆがみを数理的アプローチによりデジタルで再現する.

\section{2. 扇の折り上げに伴う変形の変換式}

\section{$2 \cdot 1$ 扇の形状とパラメータ}

扇は, 平面図である扇絵を等間隔に折り, 骨を挿して扇に仕立てる. 日本で発展した伝統的な扇は, 扇絵作成 における円弧の原点と，折り上げ後の円弧の中心点である扇の要の中心点は同一ではない，このため，扇は開い た時には放射状に広がり, 上下で収縮率の違う蛇腹構造となる。 また, 山谷で折り上げられた各面はゆがんだ曲 面となる. 本研究では, 十一本の骨の扇をモデルとし, 扇絵を図 1 のように, 山折及び谷折の折線ごとの二十一 からなるセクションに分け，それぞれのセクション毎に変換式を求める.

扇の骨の数及び扇面の寸法を定めると，各セクションの折り線が原点とな寸角 $\alpha$ が式（1）で示される.

$$
\alpha=2 \times \tan ^{-1} \frac{\mathrm{A}}{2 \times \mathrm{H}}
$$

$\mathrm{A}$ は扇の一つのセクションの上辺の長さ, $\mathrm{H}$ は扇絵における扇の高さで, 扇絵における円弧の原点 $\mathrm{O}$ と扇の上 辺までの長さである.

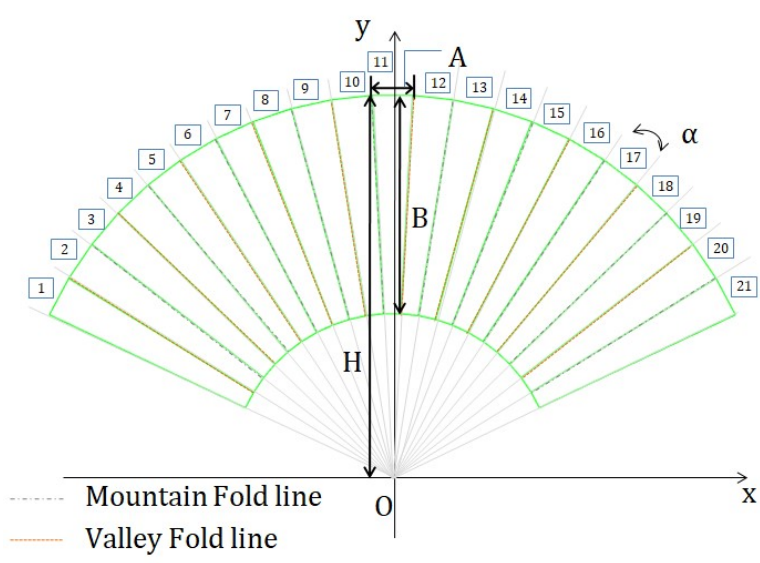

Fig. 1 The plane view of the fan face with 21 section before folding $\mathrm{s}$.

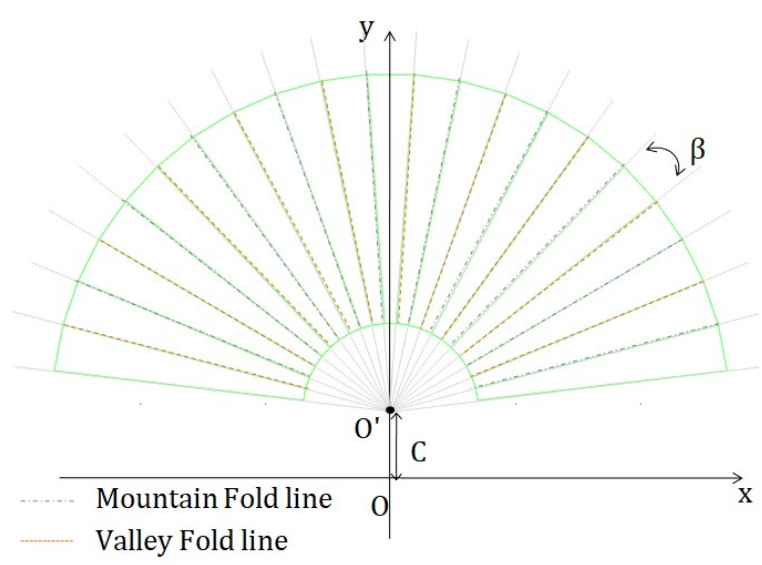

Fig. $2 \mathrm{XY}$ projection view of the fan face which is folded and fixed to the bones whose length is smaller than the length $\mathrm{H}$ by the length $\mathrm{C}$. 


\section{$2 \cdot 2$ 扇のゆがみ}

本研究の対象である，江戸期の絵師が手がけた扇は，扇絵における円弧の原点と，折り上げ後の円弧の中心点 である扇の要の中心点は同一ではない.つまり，図 2 に示すとおり原点 $\mathrm{O}$ と要の中心点 $\mathrm{O}$ の距離 $\mathrm{C}$ はゼロでは なく, 各セクションはゆがんだ曲面となる. そこで, 本研究では(1) C >0 すなわち扇骨が短い扇に仕立てる場合, 各セクションの上辺は強く引つ張られるものの元の長さを超えて伸びることはないため元の長さのままで変形せ ず, (2) C $<0$ すなわち扇骨が長い扇に仕立てる場合も同様に各セクションの下辺は元の長さのままで変形せず, (1) 及び (2) いずれの場合においても各セクション上の全ての点は, 扇の開く方向に同じ収縮率で圧縮され，折り上 げ後も平面状のセクション上に変換される, と仮定して近似的な扇の折上げ後の姿を求める.

\section{$2 \cdot 3$ 扇の中央面の図形変換式}

まず, 扇絵を扇に仕立てて開く際に生じる扇面のゆがみの処理を, 図 1 記載の扇の中央面セクション 11 に行う. 各セクション上の全ての点を, 扇の開く方向に同じ収縮率で圧縮すると仮定すると, 図 3 に示すようにセクショ ン 11 上の任意の点 $\mathrm{P}(\mathrm{x}, \mathrm{y}, \mathrm{z})$ は原点と要との距離 $\mathrm{C}$ によって点 $\mathrm{P}^{\prime}\left(\mathrm{x}^{\prime}, \mathrm{y}^{\prime}, \mathrm{z}^{\prime}\right)$ に移動する.

$\mathrm{C}>0$ の場合は図 3(a)に示すように上辺の長さは変化せず, セクション 11 上のすべての点は, 扇の要の中心点

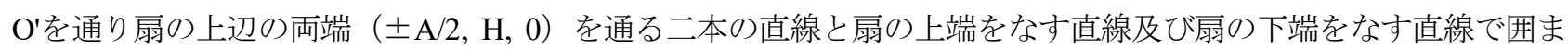
れた図形に $\mathrm{x}$ 軸方向に均等に圧縮される.この $\mathrm{x}$ 方向の圧縮率 $\mathrm{r}_{1}$ は次の通りである.

$$
\mathrm{r}_{1}=\frac{\mathrm{H}(\mathrm{y}-\mathrm{C})}{\mathrm{y}(\mathrm{H}-\mathrm{C})}
$$

$\mathrm{C}$ は扇絵における円弧の原点 $\mathrm{O}$ と要の中心点 $\mathrm{O}^{\prime}$ との距離であり, $\mathrm{y}$ はセクション 11 上の任意の点 $\mathrm{P}(\mathrm{x}, \mathrm{y}, \mathrm{z})$ の $\mathrm{y}$ 座標である.

$\mathrm{C}<0$ の場合は図 3(b)に示すように下辺の長さは変化せず, セクション 11 上のすべての点は, 扇の要の中心点 $\mathrm{O}^{\prime}$ を通り扇の下辺の両端（ $\left.\pm \mathrm{A}(\mathrm{H}-\mathrm{B}) / 2 \mathrm{H}, \mathrm{H}-\mathrm{B}, 0\right)$ を通る二本の直線と扇の上端をなす直線及び扇の下端をなす直線 で囲まれた図形に $\mathrm{x}$ 軸方向に均等に圧縮する。この $\mathrm{x}$ 方向の圧縮率 $\mathrm{r}_{2}$ は次の通りである.

$$
\mathrm{r}_{2}=\frac{(\mathrm{y}-\mathrm{C})(\mathrm{H}-\mathrm{B})}{\mathrm{y}(\mathrm{H}-\mathrm{B}-\mathrm{C})}
$$

ここで B は扇面縦寸法である.
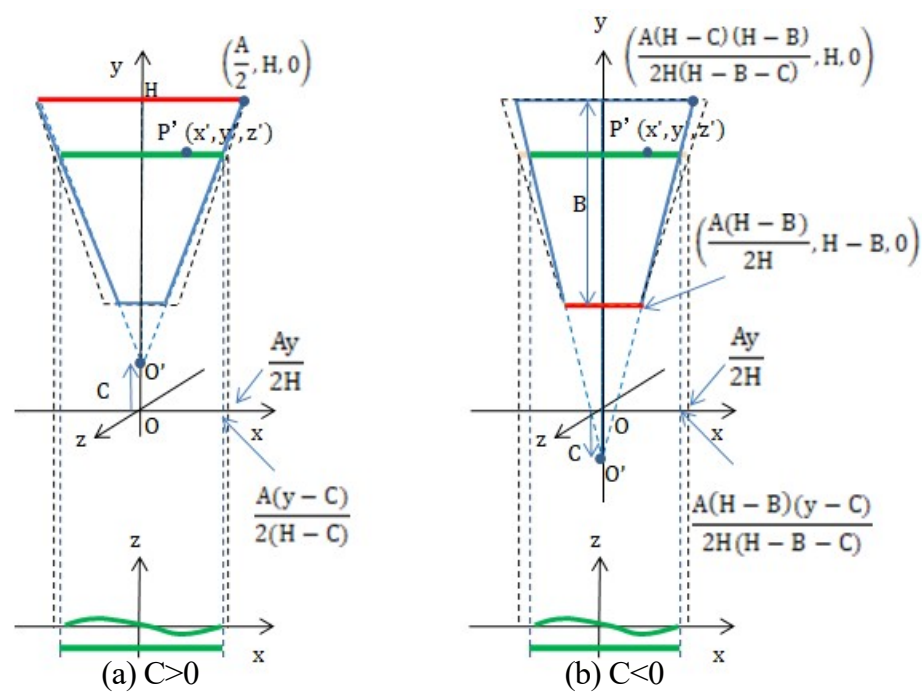

Fig. 3 The coordinates of the point in the section 11 for calculating the coordinate of the point $\mathrm{P}^{\prime}$ in two cases depending on the value of $\mathrm{C}$. 
従って, セクション 11 上の任意の点 $\mathrm{P}(\mathrm{x}, \mathrm{y}, \mathrm{z})$ が扇の折り上げに伴って移動した点 $\mathrm{P}^{\prime}\left(\mathrm{x}^{\prime}, \mathrm{y}^{\prime}, \mathrm{z}\right)$ は次の式(4)の通 りである.

$$
\mathrm{P}^{\prime}\left(\mathrm{x}^{\prime}, \mathrm{y}^{\prime}, \mathrm{z}^{\prime}\right)=(\mathrm{xr}, \mathrm{y}, 0)
$$

なお, $\mathrm{r}$ は $\mathrm{C}>0$ の時は $\mathrm{r}_{1}, \mathrm{C}=0$ の時は $1, \mathrm{C}<0$ の時は $\mathrm{r}_{2}$ の圧縮率である.

次に図 4 に示す通り点 $\mathrm{P}^{\prime}\left(\mathrm{x}^{\prime}, \mathrm{y}^{\prime}, \mathrm{z}^{\prime}\right)$ を $\mathrm{y}$ 軸周りに角度 $\theta$ 回転し点 $\mathrm{Q}\left(\mathrm{x}^{\prime \prime}, \mathrm{y}^{\prime \prime}, \mathrm{z}^{\prime \prime}\right)$ に移動する. また図 5 に示す通り, それぞれのセクションの $\mathrm{xy}$ 平面とな寸角 $\theta$ から, 折り上げ後の $\mathrm{z}$ 軸方向から見た扇の 1 セクションの開き角度 $\beta$ を次のように表すことができる.

$$
\begin{gathered}
\mathrm{Q}\left(\mathrm{x}^{\prime \prime}, \mathrm{y}^{\prime \prime}, \mathrm{z}^{\prime \prime}\right)=\left(\mathrm{x}^{\prime} \cos \theta, \mathrm{y}^{\prime},-\mathrm{x}^{\prime} \sin \theta\right) \\
=(\mathrm{xr} \cos \theta, \mathrm{y},-\mathrm{xr} \sin \theta) \\
\beta= \begin{cases}2 \tan ^{-1}\left\{\frac{\mathrm{A} \operatorname{co}}{2(\mathrm{H}-\mathrm{C})}\right\} & (\text { if } \mathrm{C} \geq 0) \\
2 \tan ^{-1}\left\{\frac{\mathrm{A}(\mathrm{H}-\mathrm{B}) \cos \theta}{2 \mathrm{H}(\mathrm{H}-\mathrm{B}-\mathrm{C})}\right\} & (\text { if } \mathrm{C}<0)\end{cases}
\end{gathered}
$$

以上の変換により, 扇絵の中央セクションであるセクション 11 上のすべての点は, 折り上げ後の扇のセクシ ヨン 11 上に移動する.
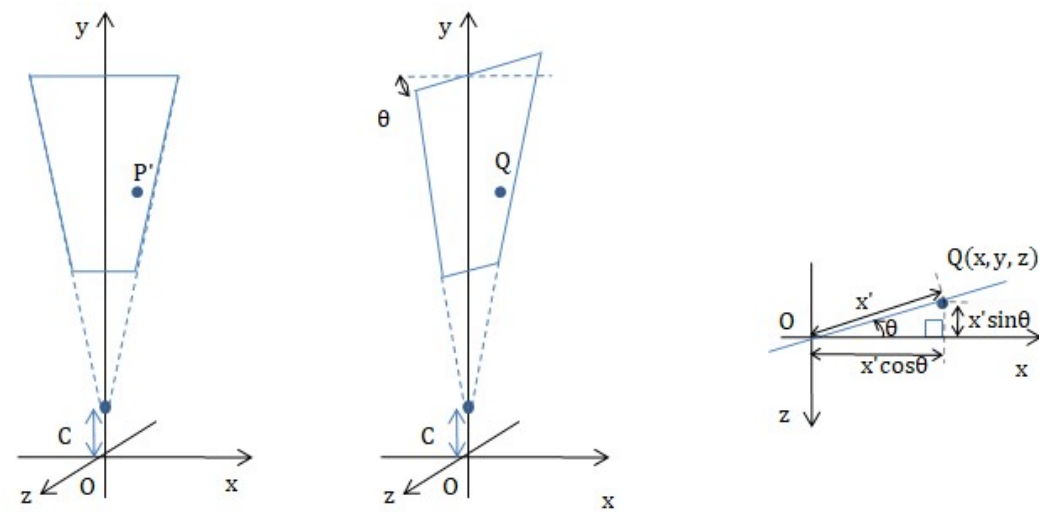

Fig. 4 Movement of the point $\mathrm{P}^{\prime}$ to the point $\mathrm{Q}$ when the section 11 is rotated by theta around $\mathrm{y}$ axis.

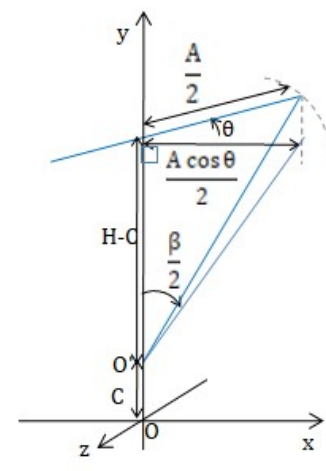

(a) $\mathrm{C}>0$

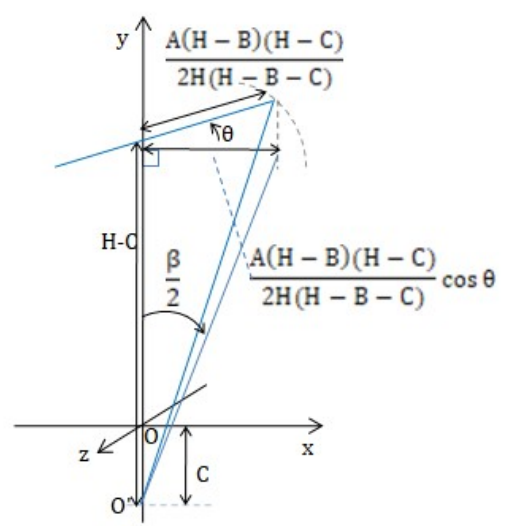

(b) $\mathrm{C}<0$

Fig.5 The length and angles of the section 11 after the fan is folded in two cases depending on the value of C. 


\section{$2 \cdot 4$ 扇の中央面以外の面の図形変換式}

扇の中央面以外の面については，まず扇絵のそれぞれのセクションごとに全ての点を原点 $\mathrm{O}$ を心に $\mathrm{xy}$ 平面 上で回転移動し，折り上げ前の中央面セクション 11 の位置まで移動する，そして，2・3 節に示したセクション 11 に対する変換を行う. その後変換後の点すべてを, 扇の要の中心点 $\mathrm{O}$ ’中心 とで, 折上げ後の其々のセクションの位置に移動させる. 図 6 にセクション 12 の扇折上げに伴う扇面上の点の移 動を示す.

セクション 12 上の寸べての点の扇絵から扇への変換は以下の式(7)から(10)で示される.

最初に, セクション 12 上のすべての点 $\mathrm{P}$ を原点 $\mathrm{O}$ を中心として $\mathrm{z}$ 軸回り正の方向に角度 $\alpha$ 回転移動し, 次に 扇骨の要の位置 $\mathrm{O}^{\prime}$ こって異なる圧縮率 $\mathrm{r}$ で $\mathrm{x}$ 方向に圧縮する.ささら折り上げに伴い, $\mathrm{y}$ 軸周りに角度 $\theta$ だけ $\mathrm{y}$ 軸回り負の方向に回転移動したのち，点 $\mathrm{O}^{\prime}$ 中心として角度 $\beta$ だけ z 軸回り負の方向に回転移動する.

$$
\begin{aligned}
& \mathrm{P}^{\prime}\left(\begin{array}{l}
\mathrm{x}^{\prime} \\
\mathrm{y}^{\prime} \\
\mathrm{z}^{\prime}
\end{array}\right)=\left(\begin{array}{ccc}
\cos \alpha & -\sin \alpha & 0 \\
\sin \alpha & \cos \alpha & 0 \\
0 & 0 & 1
\end{array}\right) \mathrm{P} \\
& \mathrm{P}^{\prime \prime}\left(\begin{array}{l}
\mathrm{x}^{\prime \prime} \\
\mathrm{y}^{\prime \prime} \\
\mathrm{z}^{\prime \prime}
\end{array}\right)=\left(\begin{array}{l}
\mathrm{r} \\
1 \\
1
\end{array}\right) \mathrm{P}^{\prime} \\
& \mathrm{P}^{\prime \prime \prime}\left(\begin{array}{l}
\mathrm{x}^{\prime \prime \prime} \\
\mathrm{y}^{\prime \prime \prime} \\
\mathrm{Z}^{\prime \prime \prime}
\end{array}\right)=\left(\begin{array}{c}
\mathrm{x}^{\prime \prime} \cos \theta \\
\mathrm{y}^{\prime \prime} \\
-\mathrm{x}^{\prime \prime} \sin \theta
\end{array}\right) \\
& \mathrm{Q}\left(\begin{array}{l}
\mathrm{X} \\
\mathrm{Y} \\
\mathrm{Z}
\end{array}\right)=\left(\begin{array}{lll}
1 & 0 & 0 \\
0 & 1 & \mathrm{C} \\
0 & 0 & 1
\end{array}\right)\left(\begin{array}{ccc}
\cos \beta & \sin \beta & 0 \\
-\sin \beta & \cos \beta & 0 \\
0 & 0 & 1
\end{array}\right)\left(\begin{array}{ccc}
1 & 0 & 0 \\
0 & 1 & -\mathrm{C} \\
0 & 0 & 1
\end{array}\right) \mathrm{P}^{\prime \prime \prime}
\end{aligned}
$$
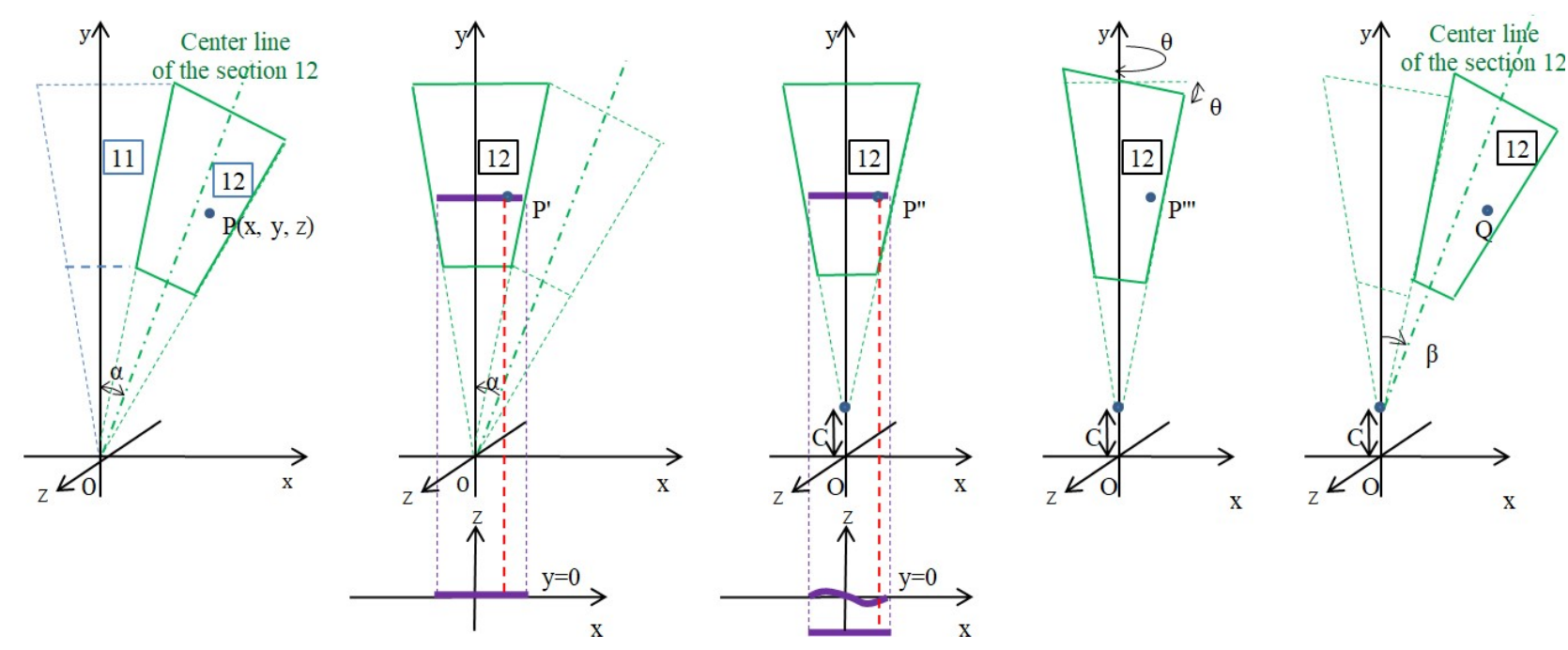

Fig. 6 Folding process of the section 12 into a fan by following the steps from Equation (7) to Equation (10).

セクション 1 10, および 13〜21 における変換式は, セクション 12 の変換式である式(7)〜(10)における角度 $\alpha$ 及び $\theta$ を, 式(11)及び式(12)に示寸それぞれのセクションの該当寸る角度 $\alpha_{i}$ 及び $\theta_{i}$ に置き換えることで得られる. なお，i は 1 から 21 までのセクション番号である.

$$
\alpha_{i}=(i-11) \alpha
$$




$$
\theta_{\mathrm{i}}=\left\{\begin{array}{cl}
\theta & \text { if } \mathrm{i} \text { is odd } \\
-\theta & \text { if } \mathrm{i} \text { is even }
\end{array}\right.
$$

\section{3. 折上げ後の扇の形と表面画像の変化}

\section{$3 \cdot 1$ 要の位置による扇の形の変化}

2 章の変換式を長さが異なる扇骨で仕立てた九種類の扇のモデルに適用する．図７の通り，扇の上辺から要の 中心点までの長さを $115 \mathrm{~mm}$ から $235 \mathrm{~mm}$ まで $15 \mathrm{~mm}$ 毎に変えて仕立てる.この時，扇絵作成における円弧の原点 と要の中心点との距離 C も $15 \mathrm{~mm}$ ずつ一 $60 \mathrm{~mm}$ から $60 \mathrm{~mm}$ の間で変化する。また，扇面縦寸法を扇骨の長さで除 した扇面比は C の大きい順から $87 \% ， 77 \% ， 69 \% ， 63 \% ， 57 \% ， 53 \% ， 49 \% ， 45 \% ， 43 \%$ ある。 なお，変数 C 以 外の変数は, $\mathrm{A}=20 \mathrm{~mm}, \mathrm{H}=175 \mathrm{~mm}, \mathrm{~B}=100 \mathrm{~mm}, \theta=8^{\circ}$ のモデルとする.

図 8 に C = 60， 0，-60mm の扇を折り上げ後のモデルを示す. $\mathrm{C}=60 \mathrm{~mm}$ では扇骨が短く扇面に要が近くなり，扇 の下辺が内側にすぼまって要に近い場所で大きく収縮している. $\mathrm{C}=0 \mathrm{~mm}$ では扇の上辺と下辺で収縮率が同じ蛇 腹に折り上げられている. $\mathrm{C}=-60 \mathrm{~mm}$ では扇骨が長く扇面から要が離れており，扇の下辺が外側に伸び，さらに 上辺が収縮している．図９に九種類の扇骨の長さで扇に仕立てた扇面を， $\mathrm{z}$ 軸方向からの視点で重ねて示してい る. $\mathrm{C}=0 \mathrm{~mm}$ 扇を中心として, C の值が大きくなってゆくほど扇面下辺が収縮してゆき，Cの值がマイナスに減 ってゆくほど扇面上辺が収縮してゆく様子がこの困からも確認できる.

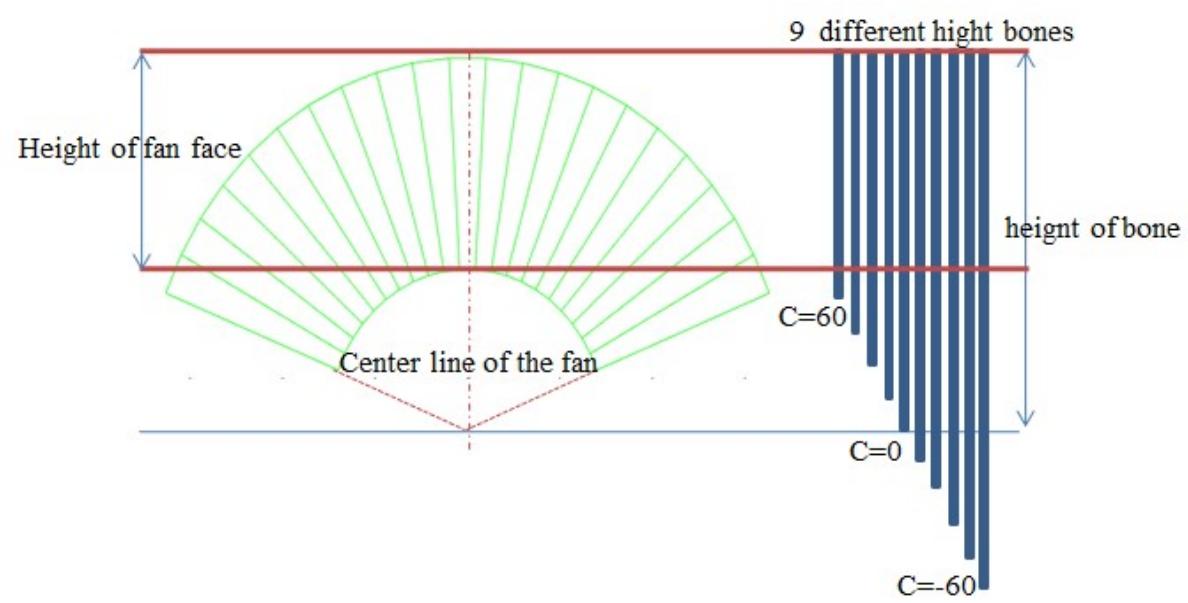

Fig.7 Fan face with nine different height bones.

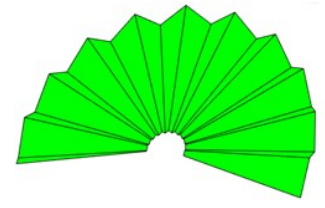

(1) $\mathrm{C}=60$

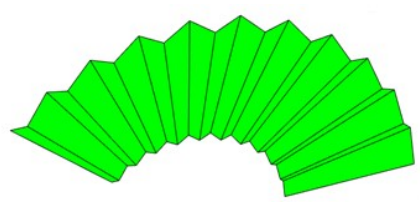

(2) $\mathrm{C}=0$

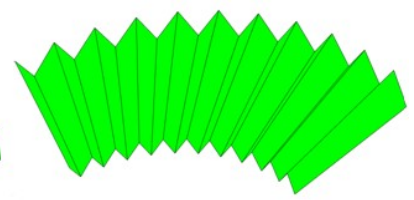

(3) $\mathrm{C}=-60$

Fig. 8 Examples of the folded fan models with three different value of $\mathrm{C}$. Those shapes are significantly different.

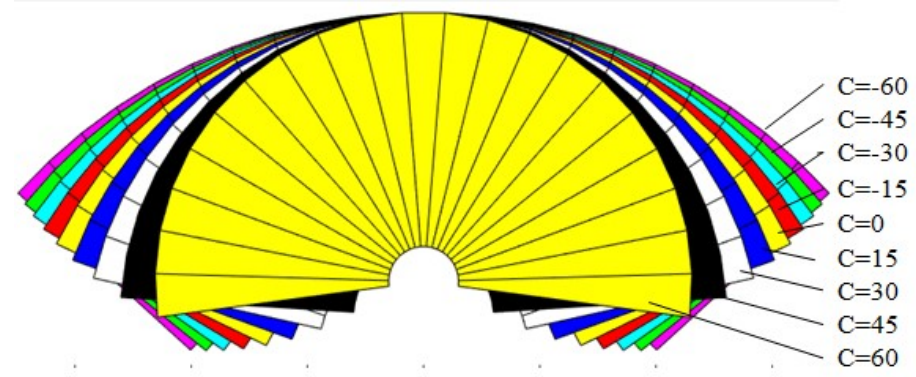

Fig. 9 xy projection view of the folded fan models shows different shapes depending the value of C. 


\section{$3 \cdot 2$ 扇上の図形の変形}

次に, 扇絵に描かれた画像が扇に折り上げられることによってどのようにゆがみ変形するか示す.図 10 の通り, 折り上げ前の扇面に扇面中心線で線対称となるように同じ大きさの正方形を三個配置し，扇骨の長さを $3 \cdot 1$ 節と 同様に九種類に変化させて九種類の扇に仕立てる．扇の各パラメータは $3 \cdot 1$ 節の值と同じ值にする.

デジタル上で扇を折り上げた画像が図 11 である. Cの值によって，それぞれ上辺側もしくは下辺側の収縮が起 こり，その収縮に忘じて扇絵に描画した正方形が変形している. 図 12 にデジタルの扇モデルと同じ寸法で仕立て ている実物の扇を示す.

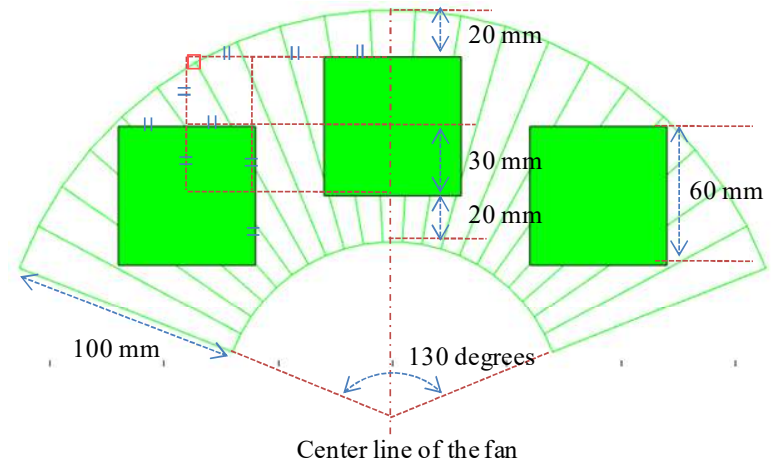

Fig. 10 Fan face with three squares to visualize the deformation of the surface image.

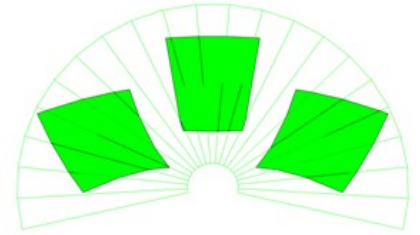

(1) $\mathrm{C}=60$, Aspect ratio 87

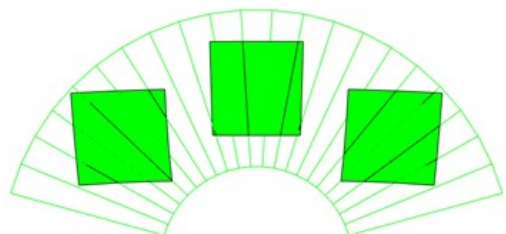

(4) $\mathrm{C}=15$, Aspect ratio 63

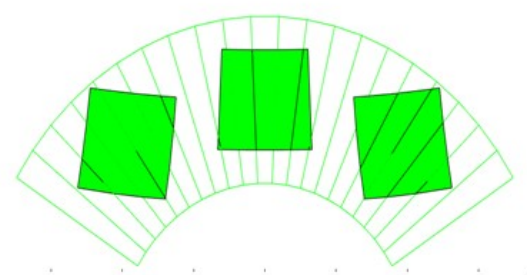

(7) $\mathrm{C}=-30$, Aspect ratio 49

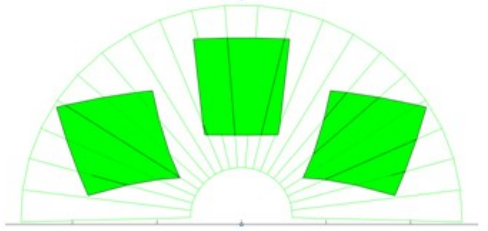

(2) $C=45$, Aspect ratio 77

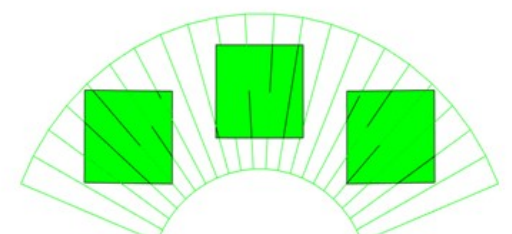

(5) $\mathrm{C}=0$, Aspect ratio 57

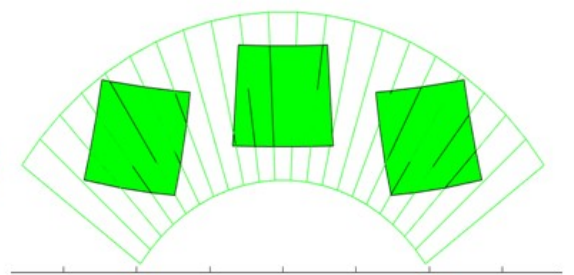

(8) $\mathrm{C}=-45$, Aspect ratio 45

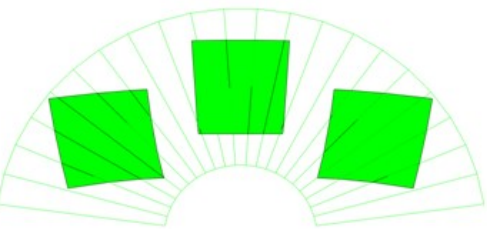

(3) $C=30$, Aspect ratio 69

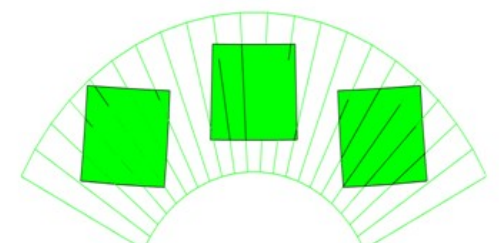

(6) $C=-15$, Aspect ratio 53

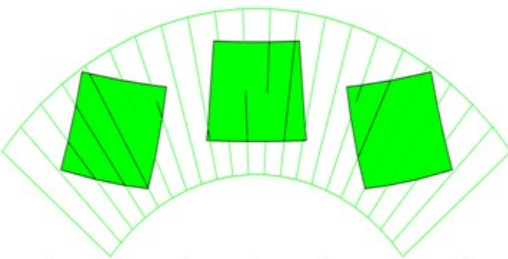

(9) $\mathrm{C}=-60$, Aspect ratio 43

Fig.11 The images of the fan model in six cases ,where the value of $\mathrm{C}$ is $-60,-45,-30,-15,0,15,30,45$ or 60 , shows that the shapes of the fan face transform depending on the value of $\mathrm{C}$, and the figures on the fan are distorted into different shapes depending not only on the value of $\mathrm{C}$ but also on their position within the fan face. 


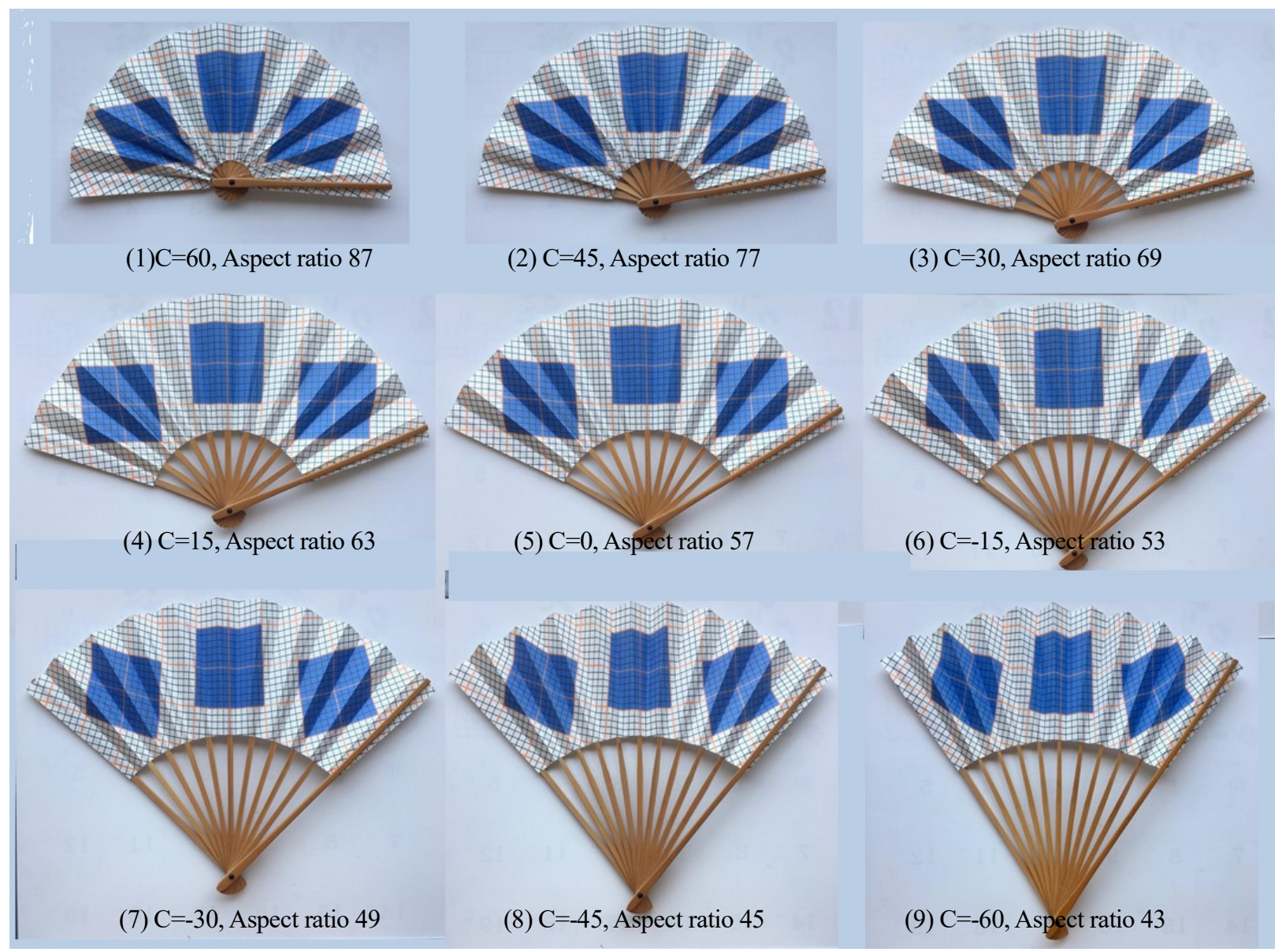

Fig. 12 Distorted surface images on the actual fans $(-60 \leqq \mathrm{C} \leqq 60)$. Those actual fan for verifying the accuracy of the digital model show that the shape of the fan and the appearance of the surface image differ depending on the value of $\mathrm{C}$.

ここで，デジタル扇のモデルが実際の扇の表面画像を再現できているか確認するため，実物の扇の形と表面図 形の比較を行う。この実物の扇は共著者である阿部が実用新案登録 3083621 号「扇面折りガイドシート」に則り 作成したものである.

実物の扇の形と表面図形の比較を行うために, 図 11 で得られたデジタル扇に次の二点の変更を行う.

一点目は, デジタル扇の開き角度を写真の実物の扇の開き角度に合わせるものである. 実物の扇は, 紙の材質、 骨の材質、これらの長さなどに応じて安定してある角度で開いたまま停止するため, デジタル扇と実物の扇の写 真を重ね合わせて形状が最も一致する角度に, 0 度から90 度の間でデジタル扇と実物の扇の写真を重放合わせて 比較し，デジタル扇の各セクションの傾き $\theta$ を決定する。 この $\theta$ を定めると式（6）より $\mathrm{z}$ 軸方向から見た扇の 1 セクションの開き角度 $\beta$ が得られる。

二点目は，実際に撮影された実物の扇とデジタル扇との座標系を合わせるものである．実物の扇の画像にデジ タル扇を重ね合わせる際には,デジタル扇を動かして頂点の位置のズレが最小になる位置を探した. 具体的には, 実物の扇の写真の扇の中央セクションの中心線を $\mathrm{y}$ 軸に固定した画像にデジタル扇の画像を重ね合わせ，これら の画像が最も一致するように $\mathrm{x}$ 軸周りにデジタル扇を角度 $\gamma$ だけ回転させる. 表 3 や表 4 を見ると幾つか頂点位 置にズレが見られるが，図 16 を見ると両者はかなり正確に一致している.

この二点の修正によりデジタル扇と実物の扇の写真を重ね合わせ形状が最も一致する $\theta, \beta, \gamma$ Cの值ごとに 表 1 にまとめる. 
Table 1 The list of $\theta, \beta, \gamma$ for each value of $\mathrm{C}$ modified so that the shapes of the digital fan and the real fan match best.

\begin{tabular}{|c|c|c|c|c|c|c|c|c|c|}
\hline (degree) \\
\hline $\mathrm{C}$ & $-60 \mathrm{~mm}$ & $-45 \mathrm{~mm}$ & $-30 \mathrm{~mm}$ & $-15 \mathrm{~mm}$ & $0 \mathrm{~mm}$ & $15 \mathrm{~mm}$ & $30 \mathrm{~mm}$ & $45 \mathrm{~mm}$ & $60 \mathrm{~mm}$ \\
\hline$\theta$ & 20. & 16 & 12 & 11 & 6 & 7 & 16 & 20 & 20 \\
\hline$\beta$ & 3.4 & 3.9 & 4.6 & 5.3 & 7 & 7 & 8 & 8 & 9 \\
\hline$\gamma$ & 3 & 2 & 2 & 1 & 1 & 1 & 1 & 1 & 1 \\
\hline
\end{tabular}

また，実物の扇の開き角度と撮影の角度によるズレの修正を行った例を図 13 に $=60$ の場合で示す.

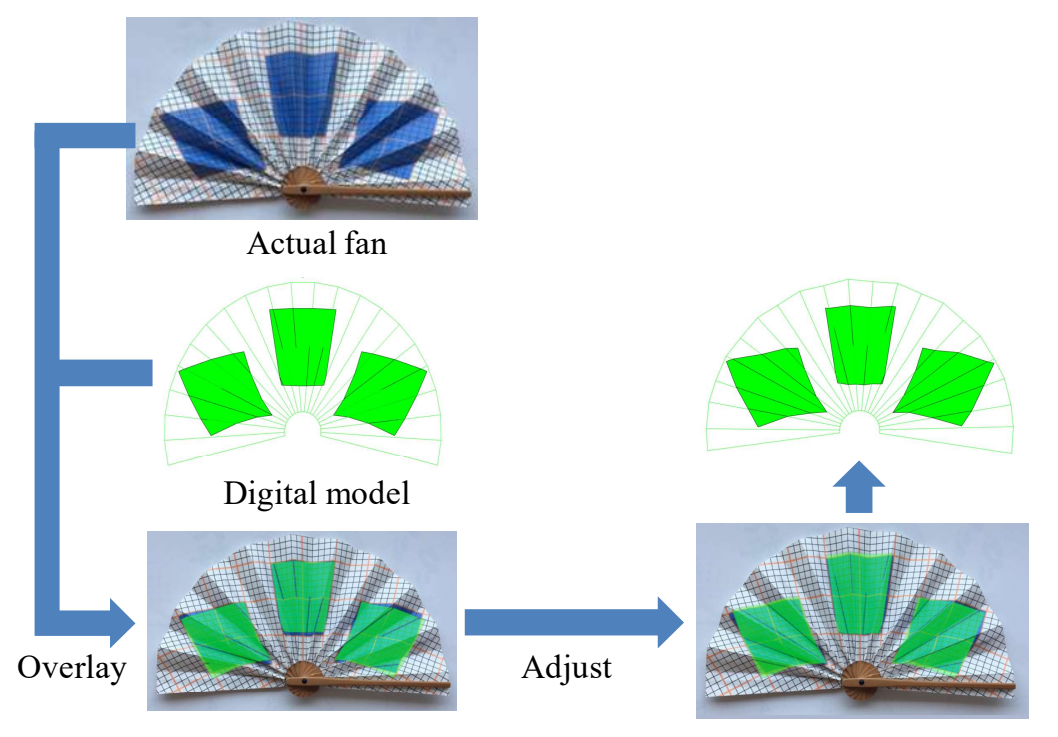

(1) $\gamma=0$ degree, $\theta=8$ degrees

(2) $\gamma=1$ degree, $\theta=20$ degrees

Fig. 13 An example of adjusting the angles when $\mathrm{C}$ is 60 . The digital fan is overlaid on the photo of the actual fan, the opening angle of the fan is adjusted and the position of the digital fan is adjusted by rotating $\gamma$ degrees around the $\mathrm{x}$-axis to match the coordinates of the two fans.

同様の角度調整を施した九種類のデジタル扇の図形を実物の扇に重㸚合わせたものが図 14 である.実物の扇上 の図形は青色，デジタル扇上の図形は緑色で表示している，九種類すべての扇で表面画像の形及び大きさがデジ タルで再現できていることが確認できる. 再現の精度を検討するため, 扇上の図形の面積を比較したものが表 2 , 頂点の位置の差を計測したものが表 3 である. 表 2 では, 図形の面積の差は扇面の面積に比べると最大で $9.91 \%$, 最小で $0.05 \%$ ，平均で $2.31 \%$ となっており，27 個の図形のうち 3 個の図形で $5 \%$ を超えるような大きな差が生じ ている.この大きな差が生じている部分を赤字で表示している. 


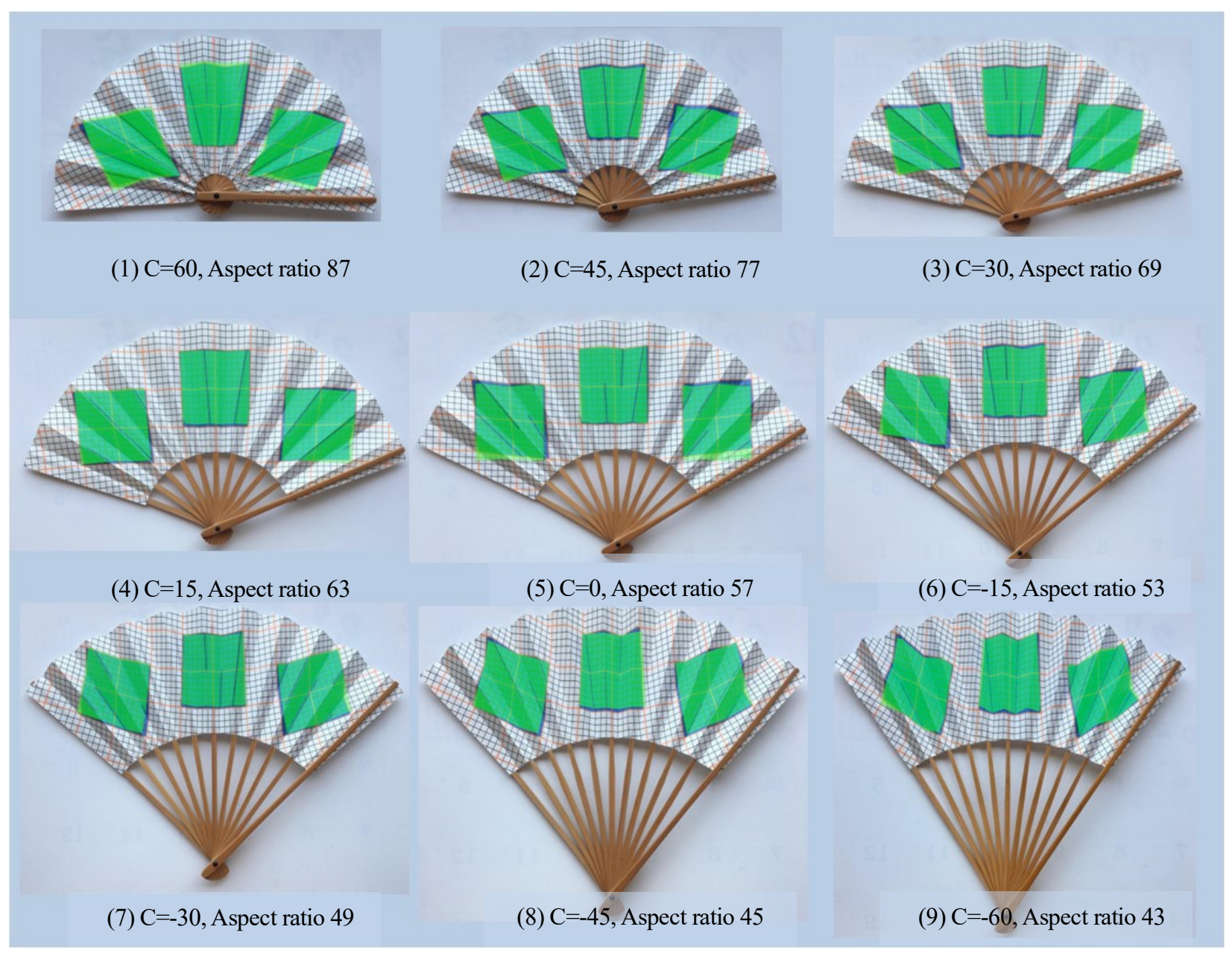

Fig. 14 Comparison of the surface images on the actual fans and the model fans $(-60 \leqq C \leqq 60)$. The surface image on the actual fan can be reproduced well on a digital fan.

Table 2 Area of figures to examine the similarity. The deviation is relatively large in three figures, but the it is small in other twenty-seven figures.

\begin{tabular}{|c|c|c|c|c|c|c|c|c|c|c|c|c|c|c|}
\hline & & \multicolumn{2}{|c|}{ Area of figures } & \multirow[b]{2}{*}{ Difference } & & & \multicolumn{2}{|c|}{ Area of figures } & \multirow[b]{2}{*}{ Difference } & & & \multicolumn{2}{|c|}{ Area of figures } & \multirow[b]{2}{*}{ Difference } \\
\hline & & Actual Ougi & Model & & & & Actual Ougi & Model & & & & Actual Ougi & Model & \\
\hline \multirow[t]{3}{*}{$\mathrm{C}=60$} & & $2,379.09$ & $2,614.92$ & $9.91 \%$ & \multirow[t]{3}{*}{$\mathrm{C}=15$} & & $3,050.17$ & $3,070.88$ & $0.68 \%$ & \multirow[t]{3}{*}{$\mathrm{C}=-30$} & left & $2,968.87$ & $3,000.55$ & $1.07 \%$ \\
\hline & center & $2,404.64$ & $2,416.73$ & $0.50 \%$ & & center & $3,018.74$ & $3,028.82$ & $0.33 \%$ & & center & $2,965.32$ & $3,042.85$ & $2.61 \%$ \\
\hline & right & $2,468.13$ & $2,582.83$ & $4.65 \%$ & & right & $2,976.77$ & $3,052.92$ & $2.56 \%$ & & right & $2,902.77$ & $2,989.85$ & $3.00 \%$ \\
\hline \multirow[t]{3}{*}{$\mathrm{C}=45$} & & $2,728.48$ & $2,744.36$ & $0.58 \%$ & \multirow[t]{3}{*}{$\mathrm{C}=0$} & left & $3,002.16$ & $3,033.44$ & $1.04 \%$ & \multirow{3}{*}{\multicolumn{2}{|c|}{$\mathrm{C}=-45$}} & $2,872.16$ & $2,890.58$ & $0.64 \%$ \\
\hline & center & $2,676.15$ & $2,635.29$ & $1.53 \%$ & & center & $3,004.36$ & $2,967.40$ & $1.23 \%$ & & & $2,777.70$ & $2,930.65$ & $5.51 \%$ \\
\hline & right & $2,651.69$ & $2,709.53$ & $2.18 \%$ & & right & $2,811.27$ & $2,994.02$ & $6.50 \%$ & & & $2,834.33$ & $2,883.34$ & $1.73 \%$ \\
\hline \multirow[t]{3}{*}{$\mathrm{C}=30$} & left & $3,032.98$ & $3,034.59$ & $0.05 \%$ & \multirow[t]{3}{*}{$\mathrm{C}=-15$} & left & $3,020.61$ & $3,005.60$ & $0.50 \%$ & \multirow[t]{3}{*}{$C=-60$} & left & $2,762.38$ & $2,765.92$ & $0.13 \%$ \\
\hline & center & $2,867.94$ & $2,919.79$ & $1.81 \%$ & & center & 2,991.09 & $3,008.62$ & $0.59 \%$ & & center & $2,791.06$ & $2,819.74$ & $1.03 \%$ \\
\hline & right & $2,873.53$ & $2,955.70$ & $2.86 \%$ & & right & $2,832.42$ & $2,966.44$ & $4.73 \%$ & & right & $2,641.31$ & $2,761.44$ & $4.55 \%$ \\
\hline
\end{tabular}

表 3 及び表 4 では頂点の位置の差を示している. 扇上の左の図形については，その頂点を左上から時計回りに L1，L2，L3，L4，同様に中央の図形では C1，C2，C3，C4，右の図形では R1，R2，R3，R4 とする. 実物の扇 とデジタルの扇で，それぞれの頂点の位置の差は表 3 の通りであるが，この差の值の折りたたむ前の眓形の一辺 の長さ $60 \mathrm{~mm}$ に対する比が表 3 である. 差の比は最大で $17.3 \%$, 最小で $0 \%$, 平均で $3.3 \%$ あ゙り, 比較した頂点 108 点のうち 10\%を超える差が生じた頂点が 5 点という結果になっている. この扇上の図形の面積の差とその頂 点の位置の差は，扇面の変形には扇の材料による個体差が大きいと考えられるため，ここでは参考としておきた い.またこれらの差が許容できるか否かについては，目的によって判断が異なる. 例えば，扇骨を外され元の扇 
としての形状情報がそしい扇の画像について，扇に関するパラメータを柔軟に変化させて扇骨の位置や切り落と し部分の推定及び山谷の位置判定をデジタル上で行い, 扇本来の姿を再現するためのパラメータを推定出来るよ うにすることが本研究の目的であるが，これがどこまで可能であるかは今後の実際の江戸期の扇に本手法を適用 して議論したい，共著者の阿部はその論文の中で，扇に描かれている人物の目線が客観的な解釈のできる方向を 向いていることや, 顔などの重要なものは扇の折目上には配置されないなどの傾向があり, 復元扇を何種類も作 成した上でこれらの点を総合的に検討し最も適切な再現扇を提示しているが，この扇再現に至るプロセスを江戸 期の実際の扇において本手法を適用して行い，その検討の中で改めて許容誤差についての検討を行う.

Table 3 Positional displacement of corner of the figures.

\begin{tabular}{|c|c|c|c|c|c|c|c|c|c|c|c|c|}
\hline $\mathrm{C}$ & L1 & L2 & L3 & L4 & $\mathrm{C} 1$ & $\mathrm{C} 2$ & C3 & $\mathrm{C} 4$ & $\mathrm{R} 1$ & $\mathrm{R} 2$ & R3 & R4 \\
\hline 60 & 4.0 & 0.0 & 3.0 & 4.0 & 0.0 & 1.0 & 2.5 & 2.0 & 0.8 & 5.0 & 5.0 & 2.0 \\
\hline 45 & 3.4 & 0.1 & 3.0 & 3.0 & 1.2 & 2.0 & 0.8 & 3.0 & 2.0 & 0.5 & 1.0 & 1.5 \\
\hline 30 & 4.0 & 2.0 & 3.0 & 2.0 & 1.0 & 1.0 & 2.4 & 2.4 & 0.1 & 1.1 & 0.1 & 2.0 \\
\hline 15 & 1.0 & 0.4 & 1.2 & 2.0 & 0.1 & 0.1 & 2.0 & 2.1 & 1.0 & 2.4 & 0.8 & 1.3 \\
\hline 0 & 4.5 & 0.0 & 4.7 & 6.2 & 0.0 & 0.2 & 0.2 & 0.3 & 1.0 & 6.2 & 10.4 & 4.0 \\
\hline-15 & 0.8 & 0.0 & 6.2 & 2.5 & 1.3 & 1.2 & 1.0 & 2.5 & 0.3 & 2.5 & 0.1 & 0.2 \\
\hline-30 & 2.3 & 0.1 & 2.2 & 5.1 & 0.2 & 0.4 & 0.1 & 1.2 & 0.1 & 0.1 & 1.8 & 0.4 \\
\hline-45 & 3.1 & 0.0 & 3.8 & 1.9 & 0.0 & 4.0 & 2.2 & 2.1 & 0.1 & 0.1 & 0.4 & 2.1 \\
\hline-60 & 6.3 & 1.1 & 4.0 & 2.7 & 1.4 & 4.3 & 4.9 & 4.6 & 0.0 & 0.9 & 1.2 & 5.3 \\
\hline
\end{tabular}

Table 4 The ratio of the positional displacement of the corers to the initial length of the figure's one side. Of the 108 vertices, only 5 points have a deviation of more than $10 \%$. Similar figures can be reproduced digitally using the digital fan model.

\begin{tabular}{|c|c|c|c|c|c|c|c|c|c|c|c|c|}
\hline $\mathrm{C}=$ & $\mathrm{L} 1$ & L2 & L3 & L4 & $\mathrm{C} 1$ & $\mathrm{C} 2$ & $\mathrm{C} 3$ & $\mathrm{C} 4$ & $\mathrm{R} 1$ & $\mathrm{R} 2$ & R3 & $\mathrm{R} 4$ \\
\hline 60 & $6.7 \%$ & $0.0 \%$ & $5.0 \%$ & $6.7 \%$ & $0.0 \%$ & $1.7 \%$ & $4.2 \%$ & $3.3 \%$ & $1.3 \%$ & $8.3 \%$ & $8.3 \%$ & $3.3 \%$ \\
\hline 45 & $5.7 \%$ & $0.2 \%$ & $5.0 \%$ & $5.0 \%$ & $2.0 \%$ & $3.3 \%$ & $1.3 \%$ & $5.0 \%$ & $3.3 \%$ & $0.8 \%$ & $1.7 \%$ & $2.5 \%$ \\
\hline 30 & $6.7 \%$ & $3.3 \%$ & $5.0 \%$ & $3.3 \%$ & $1.7 \%$ & $1.7 \%$ & $4.0 \%$ & $4.0 \%$ & $0.2 \%$ & $1.8 \%$ & $0.2 \%$ & $3.3 \%$ \\
\hline 15 & $1.7 \%$ & $0.7 \%$ & $2.0 \%$ & $3.3 \%$ & $0.2 \%$ & $0.2 \%$ & $3.3 \%$ & $3.5 \%$ & $1.7 \%$ & $4.0 \%$ & $1.3 \%$ & $2.2 \%$ \\
\hline 0 & $7.5 \%$ & $0.0 \%$ & $7.8 \%$ & $10.3 \%$ & $0.0 \%$ & $0.3 \%$ & $0.3 \%$ & $0.5 \%$ & $1.7 \%$ & $10.3 \%$ & $17.3 \%$ & $6.7 \%$ \\
\hline-15 & $1.3 \%$ & $0.0 \%$ & $10.3 \%$ & $4.2 \%$ & $2.2 \%$ & $2.0 \%$ & $1.7 \%$ & $4.2 \%$ & $0.5 \%$ & $4.2 \%$ & $0.2 \%$ & $0.3 \%$ \\
\hline-30 & $3.8 \%$ & $0.2 \%$ & $3.7 \%$ & $8.5 \%$ & $0.3 \%$ & $0.7 \%$ & $0.2 \%$ & $2.0 \%$ & $0.2 \%$ & $0.2 \%$ & $3.0 \%$ & $0.7 \%$ \\
\hline-45 & $5.2 \%$ & $0.0 \%$ & $6.3 \%$ & $3.2 \%$ & $0.0 \%$ & $6.7 \%$ & $3.7 \%$ & $3.5 \%$ & $0.2 \%$ & $0.2 \%$ & $0.7 \%$ & $3.5 \%$ \\
\hline-60 & $10.5 \%$ & $1.8 \%$ & $6.7 \%$ & $4.5 \%$ & $2.3 \%$ & $7.2 \%$ & $8.2 \%$ & $7.7 \%$ & $0.0 \%$ & $1.5 \%$ & $2.0 \%$ & $8.8 \%$ \\
\hline
\end{tabular}

\section{$3 \cdot 3$ 扇上の図形の変形の逆算}

3 ・2 節において，要の位置を変化させて扇に折り上げることによって，平面に描かれた図形が，それぞれ異な るゆがみの図形に変化することが確認できたが，この節では逆に，扇の特性を生かした商品開発において重要と なる,「扇に折り上げた際に目的と寸る図形を表示するための, 元となる平面画像を求める」という点において 2 章の変換式が機能するかどうか確認する.

変数 C ごとに折り上げた扇面比のそれぞれ異なる扇で，扇の正面すなわち $\mathrm{z}$ 軸方向から見て同じ大きさの正方 形が扇面中心線で線対称に見えるように扇を仕立てる. 目的とする画像を図 15 に示す.

図 15 の画像を表現する扇面を，2 章の変換式を逆算的に適用して平面に展開し，図 16 の扇絵が得られた. 


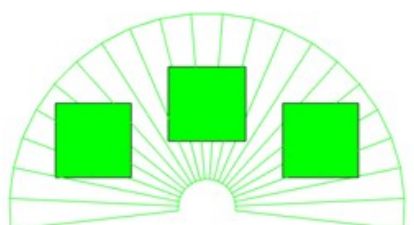

(1) $\mathrm{C}=60$, Aspect ratio 87

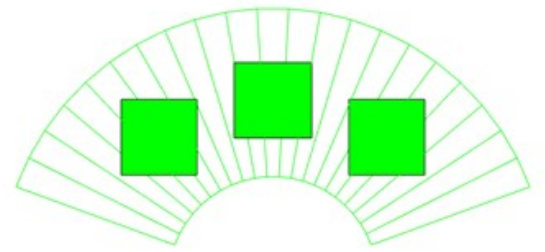

(4) $C=15$, Aspect ratio 63

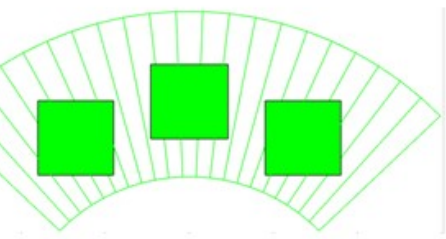

(7) $C=-30$, Aspect ratio 49

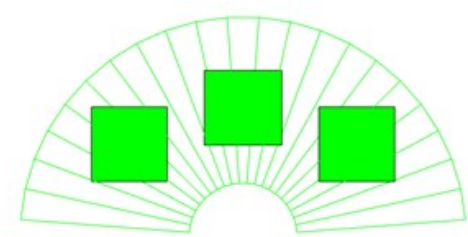

(2) $\mathrm{C}=45$, Aspect ratio 77

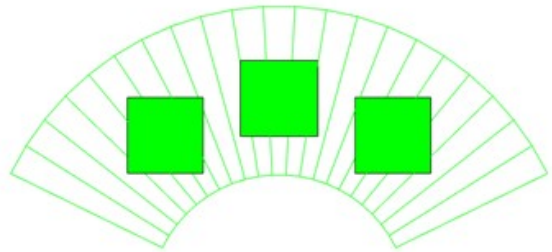

(5) $\mathrm{C}=0$, Aspect ratio 57

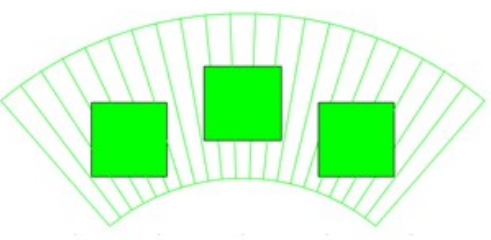

(8) $\mathrm{C}=-45$, Aspect ratio 45

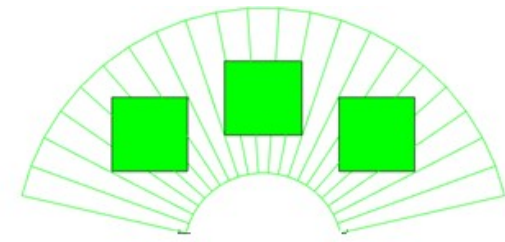

(3) $C=30$, Aspect ratio 69

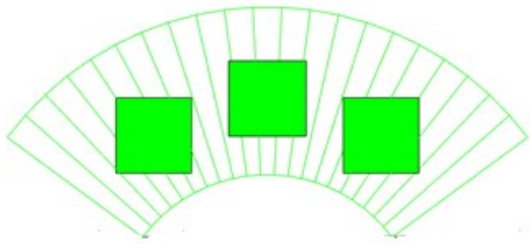

(6) $\mathrm{C}=-15$, Aspect ratio 53

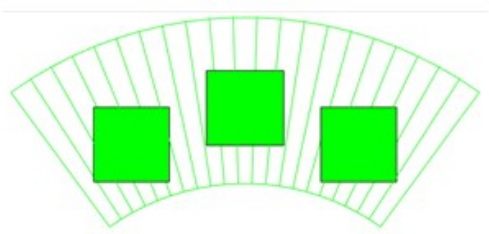

(9) $\mathrm{C}=-60$, Aspect ratio 43

Fig. 15 Three squares projected on the folded fan models $(-60 \leqq \mathrm{C} \leqq 60)$.

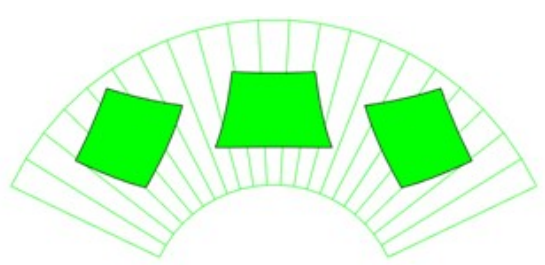

(1) $\mathrm{C}=60$, Aspect ratio 87

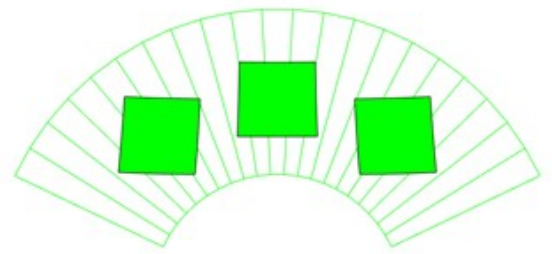

(4) $C=15$, Aspect ratio 63

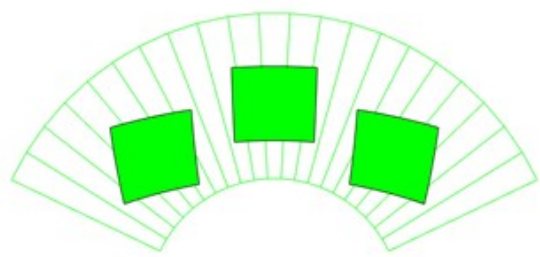

(7) $\mathrm{C}=-30$, Aspect ratio 49

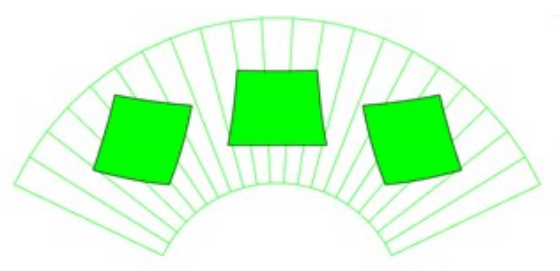

(2) $\mathrm{C}=45$, Aspect ratio 77

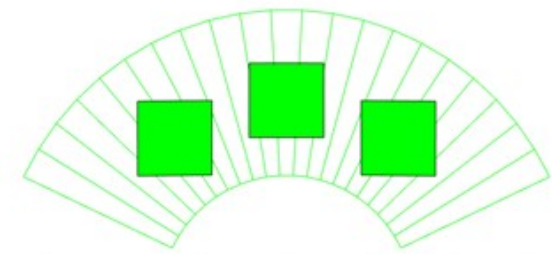

(5) $\mathrm{C}=0$, Aspect ratio 57

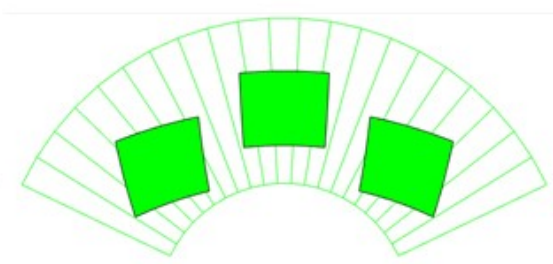

(8) $\mathrm{C}=-45$, Aspect ratio 45

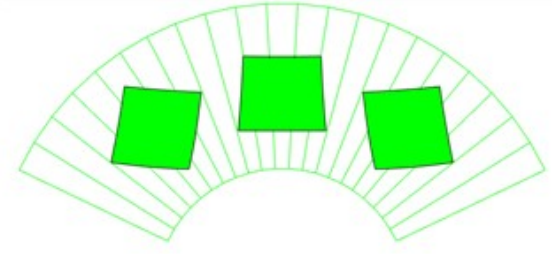

(3) $\mathrm{C}=30$, Aspect ratio 69

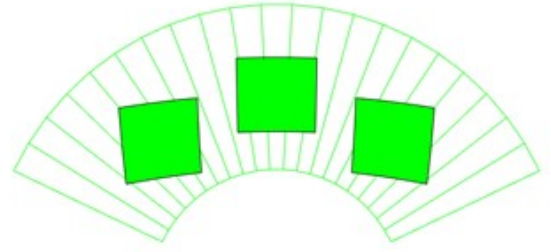

(6) $\mathrm{C}=-15$, Aspect ratio 53

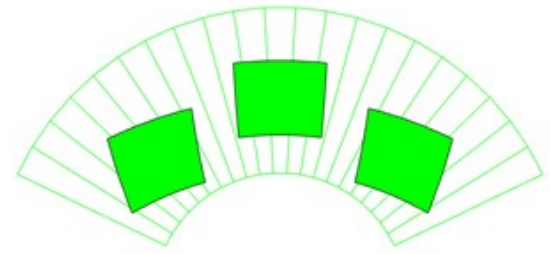

(9) $\mathrm{C}=-60$, Aspect ratio 43

Fig. 16 Plan views of the model fans $(-60 \leqq C \leqq 60)$. The larger the absolute value of $\mathrm{C}$, the more figures that does not look like a square. Also, the closer the figures are to the edge of the fan surface, the more distorted they are. 


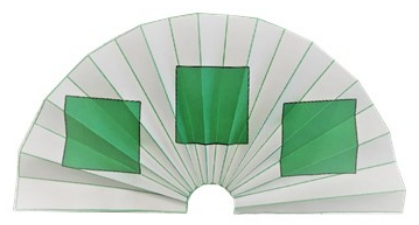

(1) $\mathrm{C}=60$, Aspect ratio 87

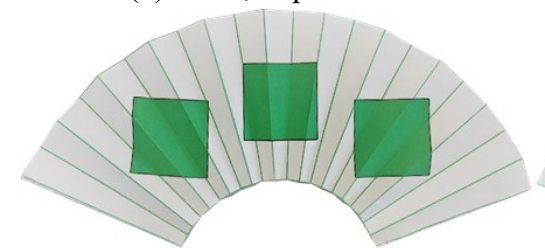

(4) $\mathrm{C}=15$, Aspect ratio 63

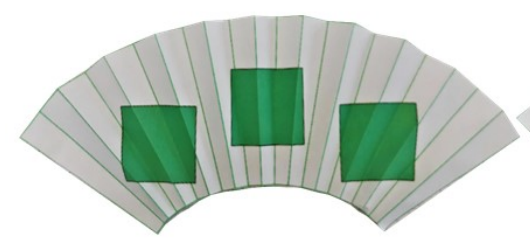

(7) $\mathrm{C}=-30$, Aspect ratio 49

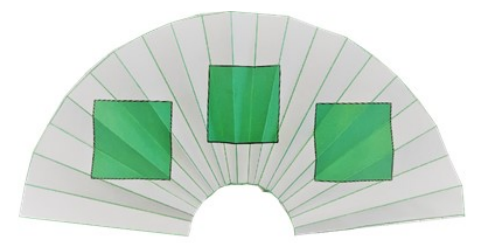

(2) $\mathrm{C}=45$, Aspect ratio 77

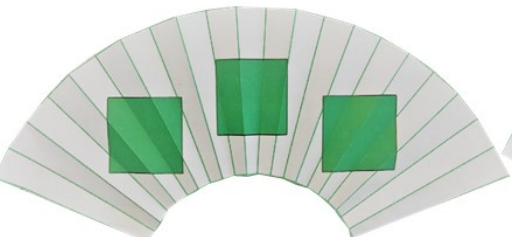

(5) $\mathrm{C}=0$, Aspect ratio 57

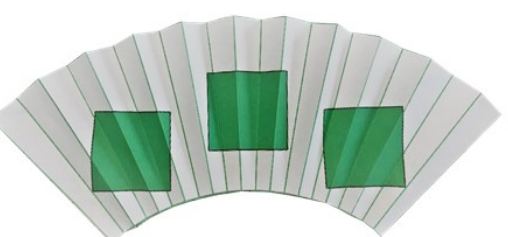

(8) $\mathrm{C}=-45$, Aspect ratio 45

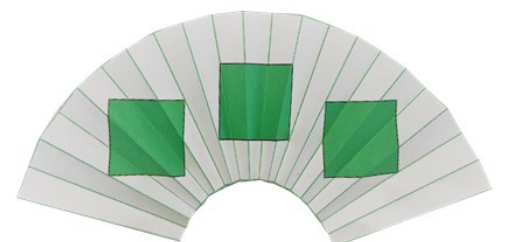

(3) $\mathrm{C}=30$, Aspect ratio 69

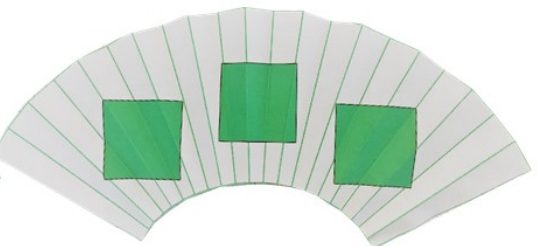

(6) $\mathrm{C}=-15$, Aspect ratio 53

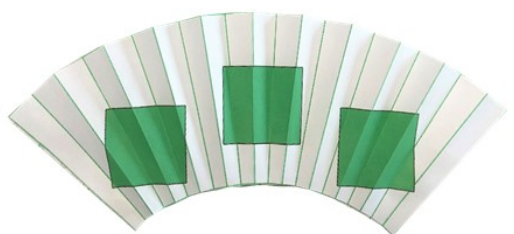

(9) $\mathrm{C}=-60$, Aspect ratio 43

Fig. 17 Folded model fans $(-60 \leqq \mathrm{C} \leqq 60)$. The figures that did not look like square in the plan view transform into figures close to square when folded up.

図 16 では，変数 C の絶対值が大きいほど，元画像の正方形からの変化は大きくゆがんでいることが分かる. $\mathrm{C}=-15 \mathrm{~mm}, 0 \mathrm{~mm}, 15 \mathrm{~mm}$ では扇絵上の図形が正方形に近い形であるが，Cの絶対值が大きい扇絵上の図形は正方形 からは大きく離れた見かけとなる.

これらのデジタルで再現した扇絵を，実際に折り上げたものが図 17 である，正面から見ると，おおむね同じ大 きさで等間隔に並んだ正方形が再現できていることが確認できる. なお, 図 17 の（8）及び（9）の両端で正方形 とはならず外側に折れる図形となっているが，これは扇の外端を固定する際に端のセクションの角度 $\theta$ が 0 に近 くなるがその補正を行わずに端のセクションに図形を投影したものに変換式を適用したためである. 実際の商品 開発や江戸期の扇の複製作業においてはこの点を考慮し，使用する紙と骨ごとに個別の補正を行わなければなら ない. なお，扇の左右端近くの折面が他の折面とは異なるゆがみを生じることは江戸期の絵師は認識しており， こうした左右端の折面近くには描画がなされないもしくは少しのゆがみでも影響の少ない線や点などの描画のみ を施している.本手法で実際の商品開発や江戸期の扇の複製を行うための基本的な方法は確立できたと考えるが， 今後は実際に竹骨と和紙を用いて扇を作成し, 商品価值のある扇の検討及び江戸期の扇の複製作業を行い, 課題 の洗い出しやその解決に取り組みたいと考える.

\section{4. 結 語}

扇絵は，扇の状態で美しく見えるようにゆがみを構図に配慮しなければならない. 江戸時代まで日本美術史に 名を連ねる絵師たちによって千年以上に亘り, 切硣环磨して築き上げられた「折」を生かした日本独自の描画法 をデジタル上で再現すべく検討し，次の結果がえられた。

(1) 平面に描画された扇絵を, 要の位置変化に対応して三次元に折り上げる画像のゆがみを考慮した近似的な 変換式を導いた。

（2）この変換式を用いて，扇の折り上げによる表面画像の見え方の変化を視覚的に確認した.

(3) 扇骨の長さを変化させると, 扇面の収縮によってゆがみが大きく生じる部分の位置が変わることが確認で きた. 
（4）近似法の妥当性を実物の扇で確認した. その際, 数度の仰角の違い及び扇の開く角度の違いによって扇面 表面図形の見え方に変化が出ており, 扇面の長さや扇骨の長さといった物理的な構成だけでなく, 扇を眺める角 度, 扇の開き方で, 扇の表面画像の表現が豊かに変わることも確認できた。

（5）また, 商品開発を目的として, 仕立て上げた扇に目的とする描画を施すために, 変換式を逆算的に用いて 元の平面図の図形を求められることを確認した.

今回は第一報として久損部分がなく折目も定まった最もシンプルなモデルで検討した。一般的には扇絵で十分 との考えから，再現まではなされないケースが多い，一方，共著者の阿部は，扇は再現することによりはじめて 作者の意図が伝わることを強調し, 自ら江戸時代の扇の作り方を特許化し再現を試みているがそれは大変な作業 である. 今回, 骨の数を最も一般的な十本から十三本の中から十一本としたが, 本報で開発した手法は骨の数や 折目を自由に変えることが出来る. 従って, 本報で提案した扇の折り上げに伴う変形の変換式を用いてデジタル 上でまず骨の数や折目を同定することで復元作業の支援が可能となると考える.

今後は, この支援により効率よく実際に竹骨と和紙を用いて扇を作成し, 商品価值のある扇の検討及び江戸期 の扇の複製作業を行い, 課題の洗い出しやその解決に取り組みたい. また, 扇のゆがみを生かした商品開発とし て, 折り上げた扇といった形状が一定の表示器だけでなく, 扇骨の長さの変化に伴う扇面の画像の変化を積極的 に生かせる表示器を検討する. 鑑賞者の位置や光の当て方などの効果についても検討を進めたい.

\section{文献}

阿部富士子, 扇絵の描画特性と再現扇を用いた復元的考察:「写楽扇面」と「源氏物語絵扇面」を例に，芸術工 学会誌, No.80 (2020), pp. 40-47.

阿部富士子, 江戸の扇にみる折りの造形〜鴻池コレクション調査より, 太田記念美術館紀要, 浮世絵研究, No. 1 (2021), pp. 65-91.

李御寧, 「縮夕」志向の日本人, 講談社 (2007), pp. 59-60.

面出和子, 扇絵の空間表現のゆがみについて, 図学研究, Vol. 41, No. 2 (2007), pp. 3-9.

朱新林, 団扇と扇子その一つ一つに込められた情感, Science Portal China (2010), available from $<$ https://spc.jst.go.jp/experiences/change/change_1004.html>, (参照日 2020 年 6 月 20 日).

\section{References}

Abe, F., A study of the unique characteristics of ougi-e drawing techniques, as highlighted by restoration processes: through examples of Sharaku ougi-e and Genji Monogatari ougi-e, Society for Design and Art Fusing with Science and Technology, No.80 (2020), pp.40-47 (in Japanese).

Abe, F., Formative features of folding fans in the Edo period "from the survey of the Kounoike collection", Bulletin of the Ota Memorial Museum of Art, Ukiyo-e Studies, No. 1(2021), pp. 65-91(in Japanese).

Lee, O., A study of Japan's tendency to make the most out of miniaturization, Kodansha (2007), pp.59-60 (in Japanese).

Mende, K., Distortion in pictorial scenes on Japanese fans, Journal of Graphic Science of Japan, Vol.41, No.2 (2007), pp.3-9 (in Japanese).

Zhu, X., Round fan and folding fan -Feelings contained in each one-, Science Portal China (2010), available from $<$ https://spc.jst.go.jp/experiences/change/change_1004.html>, (accessed on 20 June, 2020) (in Japanese). 